\title{
Investigation of Sewage and Drinking Water in Major Healthcare Centres for Bacterial and Viral Pathogens
}

\author{
Khan Suliman ${ }^{1,2}$, Rabeea Siddique ${ }^{3}$, Ghulam Nabi' ${ }^{1}$, Wasim Sajjad ${ }^{4}$, Pathiranage Prajani Mahesha Heenatigala ${ }^{1,2}$, Yang Jingjing1,2, Qingman \\ $\mathrm{Li}^{1,2}$, Hongwei Hou ${ }^{1,2 *}$ and ljaz Ali ${ }^{* *}$ \\ ${ }^{1}$ The Key Laboratory of Aquatic Biodiversity and Conservation of Chinese Academy of Sciences, Institute of Hydrobiology, Chinese Academy of Sciences, Wuhan, \\ Hubei,430072, PR China \\ ${ }^{2}$ State Key Laboratory of Freshwater Ecology and Biotechnology, Institute of Hydrobiology, Chinese Academy of Sciences, Wuhan, 430072, PR China \\ ${ }^{3}$ Department of Biomedical Engineering, Huazhong University of Science and Technology, Wuhan 430074, PR China \\ ${ }^{4}$ Key laboratory of petroleum resources, Gansu Province/Key laboratory of petroleum resources research, Institute of Geology and Geophysics, Chinese Academy of \\ sciences, Lanzhou 730000, PR China. \\ ${ }^{5}$ Department of Biosciences, COMSATS, Islamabad, 44000, Pakistan
}

\begin{abstract}
Water is a major source of microbes, including pathogens that can cause critical pathological conditions and outbreak of epidemics. Due to lack of proper medical waste-management system in Peshawar, most of the waste is disposed of near sewage lines which run parallel to drinking water supply increasing the chances of water contamination. This study was undertaken to examine bacterial and viral pathogens in fresh and waste water in major Health care units. Conventional culturing techniques were used to identify bacterial pathogens followed by biochemical analysis, whereas viral pathogens were detected by Polymerase Chain Reaction (PCR). Analysis of sewage and drinking water supply in major health care facilities of Peshawar city indicated that Klebsiella pneumoniae and Staphylococcus aureus were found in all water samples whereas serious health risk causing bacteria including Mycobactirium tuberculosis were also detected in some regions. Two viral pathogens, Hepatitis C virus (HCV) and Hepatitis B virus (HBV) were found in open sewage water of Khyber Teaching Hospital and Dabgari Garden (G). The presence of these pathogens in water is a serious threat to public health and the environment and calls for immediate action to enforce proper medical waste-management to eliminate the risks to human health.
\end{abstract}

Keywords: Water; Major healthcare centers; Pathogens; Public health

\section{Introduction}

Water pollution is one of the most pervasive problem afflicting people throughout the world. Waterborne illness and multiple epidemics are related to the consumption of contaminated or inadequately treated water is a global public health concern. As a developing country, Pakistan has poor water treatment system and ranked 80th among 122 nations in terms of providing good quality drinking water [1]. However, scenario is even worst in many cities of Pakistan where drinking water is unsafe for direct human consumption and severely contaminated with bacterial and viral pathogens. In Pakistan, waterborne diseases and parasitic infections due to contaminated water accounts for nearly $60 \%$ and $80 \%$ of children's death respectively. Every year approximately 250,000 children die due to water-borne diarrhoea solely and 1.2 million people get affected by waterborne pathogens in Pakistan [2]. Furthermore, scientific data and evidence considering role of waterborne pathogens in the epidemiology of hospital-acquired infections are insufficient [3]. Recent reports on pathological conditions of identified water borne pathogens have provided novel insights into the understanding of pathology and effect of diseases [4-6], which persist in numerous aquatic systems due to the advantage of resistance to various environmental factors [7].

Health facilities, mainly health care centres, hospitals, clinics and laboratories pose higher risk of water contamination since these are more likely to be the sources of viral and bacterial pathogens [811]. Although numerous research has been conducted to address the detection and origination of pathogens in both drinking water and wastewater $[12,13]$, however, insufficient studies have done explicitly about tracing the occurrence of pathogens in water sources near healthcare facilities [14,15].

Our current study was conducted to detect the presence of pathogenic microbes both in drinking and waste water samples collected from Khyber Teaching Hospital (KTH), Hayatabad
Medical Complex (HMC) and Dabgari Garden (DBG/DG), the major healthcare facilities of Peshawar, capital city of province Khyber Pakhtunkhwa (KP), Pakistan. Everyday these hospitals provide health facilities to thousands of local people, patients coming from far flung areas of KP, and from Afghanistan as well. During personal visits to these hospitals for sample collection improper sewage systems allowing stagnant water retention for several days and mass of untreated disposed materials were observed, which may stir up risk of contamination in drinking water. In addition, the disposal of waste materials from diagnostic laboratories and pharmaceutical centres poses a significant threat to public health.

Inadequate information is available about sewage and drinking water quality near major health care units of Peshawar, KP, Pakistan and no investigation for pathogens has been done particularly considering water sources of the healthcare centers. Additionally, no pre-defined rules and laws presented by WHO are set and applied by healthcare management and higher authorities for such investigation and providing good quality treated water. Therefore, the focus of current study is determination of viral and

*Corresponding author: Hongwei Hou, The Key Laboratory of Aquatic Biodiversity and Conservation of Chinese Academy of Sciences, Institute of Hydrobiology, Chinese Academy of Sciences, Wuhan, Hubei, 430072, PR China, Tel: +862768780159; Fax: +862768780123; E-mail: houhw@ihb.ac.cn

Ijaz Ali, Department of Biosciences, COMSATS, Islamabad, 44000, Pakistan, Tel: +03319378337; E-mail: ijaz.ali@comsats.edu.pk

Received April 01, 2017; Accepted April 12, 2017; Published April 18, 2017

Citation: Suliman K, Siddique R, Nabi G, Li Q, Hou H, et al. (2017) Investigation of Sewage and Drinking Water in Major Healthcare Centres for Bacterial and Viral Pathogens. Hydrol Current Res 8: 272. doi: 10.4172/2157-7587.1000272

Copyright: () 2017 Suliman K, et al. This is an open-access article distributed under the terms of the Creative Commons Attribution License, which permits unrestricted use, distribution, and reproduction in any medium, provided the original author and source are credited. 
bacterial pathogens in drinking and sewage water of major health care units of Peshawar to highlight critical role contaminated water plays in waterborne diseases. Culture techniques and Polymerase Chain Reaction (PCR) as the most commonly used methods for monitoring and detection of bacterial and viral pathogens [16-19], are applied in this research.

\section{Materials and Methods}

\section{Study site description and sampling}

Khyber Pakhtunkhwa (KP) province -with population of 26.9 million and area of 74,521 square kilometer- is located in the north-western region of Pakistan and by the size of population is the $3^{\text {rd }}$ biggest province of Pakistan. Peshawar $\left(33^{\circ} 99^{\prime} 16^{\prime \prime} \mathrm{N}\right.$, $71^{\circ} 51$ ' 36 "E) is its provincial capital and largest city and hub of hospitals where patients come not only from all around the KP but also from neighbor country Afghanistan. It is crucial that hospitals providing health facility to thousands of patient's everyday have accessibility to pathogen free drinking water. In this study, total of 252 drinking and sewage water samples were examined over a period of one year from January 2013 to December 2013, samples were collected 3 times a year in 2013, in January, June and October respectively. First session of sampling was completed during last two weeks of January, second in first two weeks of June and third time samplings were done during the last two weeks of October. Totally, 126 drinking and 126 sewage water samples were collected from three major hospitals of Peshawar i.e., KTH, HMC and DG, with the interval of 4 months except the rainy days. All samples were collected in sterile bottles from the premises of these health care sites (42 different sites in total, 6 samples were collected from each site, 3-drinking, 3-sewage water samples).

\section{Filtration and DNA/RNA isolation}

Water samples were taken to lab soon after collection in ice containers and filtered through sterile filter membranes, 0.22 $\mu \mathrm{m}$, (Science laboratory, Islamabad, Pakistan) to concentrate the samples for investigation of bacterial pathogens. The whole water samples were processed through DNA/RNA isolation kit (Norgen Biotek, Canada) for the detection of viral pathogens.

\section{Screening and selective media preparation for incubation}

Screening was done for the samples collected (nutrients media) and positive samples were further tested through selective media. Selective media (Merck, Rawalpindi, Pakistan) were prepared (according to the prescription provided by Merck, Rawalpindi, PK) for the culturing of bacterial colonies (selective media shown in Table 1). Sterilized media were poured into Petri plates, followed by spreading of concentrated water samples with the help of a sterilized loop. Petri plates were incubated at $35^{\circ} \mathrm{C}$ for $24 \mathrm{~h}$ (Also 48 hours to get the correct density) and 5 weeks for MTB, followed by sub-culturing of colonies on fresh selective media at $34^{\circ} \mathrm{C}$ and $36^{\circ} \mathrm{C}$ [14]. This step of colony sub-culturing was repeated 3 times for confirmation of the resultant colonies. The colonies which showed consistent growth were noted and non-consistent growing bacterial pathogens were neglected to avoid false positive results.

\section{Biochemical analysis}

Biochemical tests conducted for identification of bacterial species grown previously on selective media were Catalase, Oxidase, Tube coagulase, Alkaline phosphatase, Motility, Arginine,

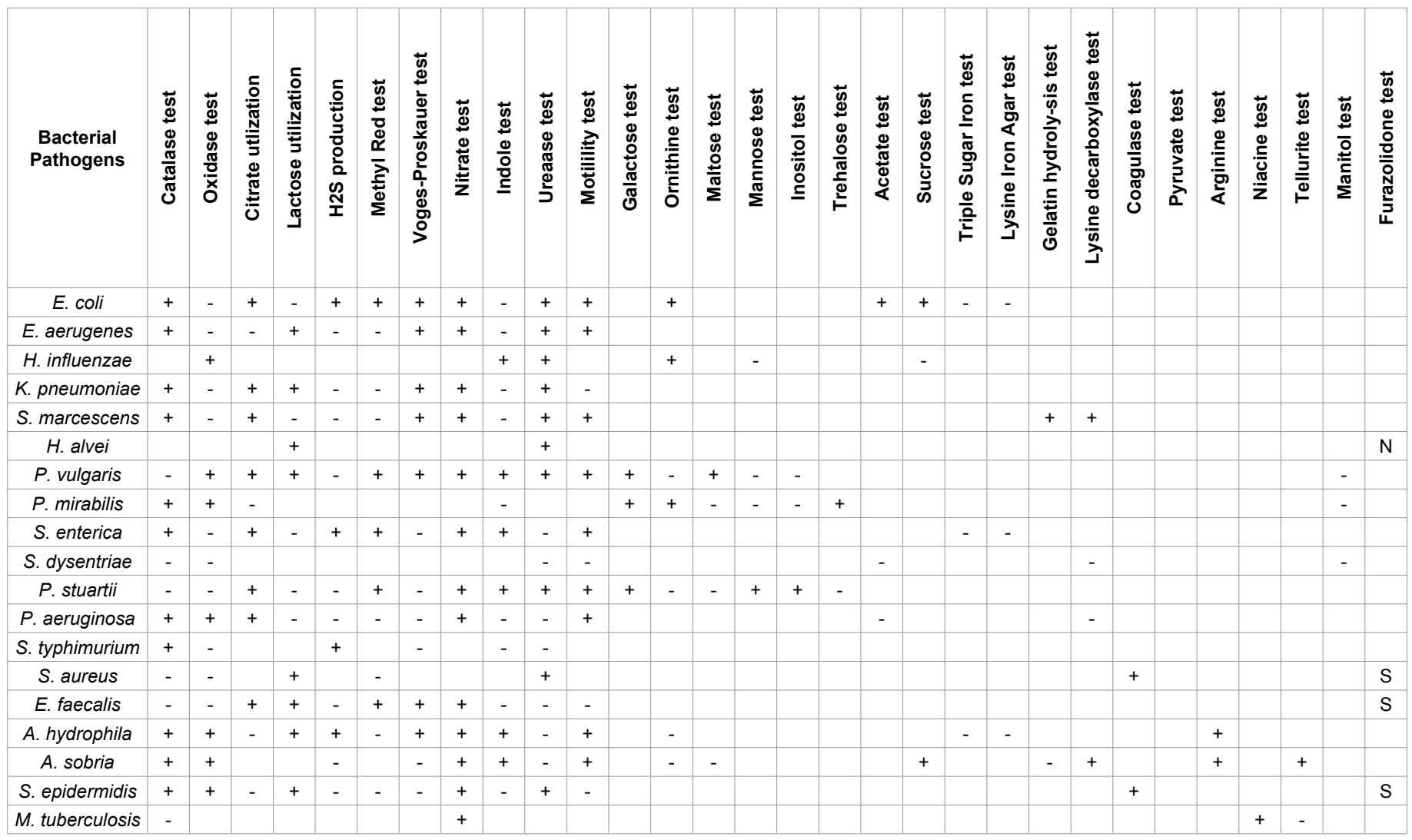

Table 1: Biochemical tests used for identification of the microorganisms at specie level. 
Pyruvate, Mannitol, Sucrose and Ornithine, Esculin, fermentation of Sucrose and Lysine decarboxylase (Table 1). Sterile loop was used to pick the bacterial colony from the selective media and tested for biochemical test. The result was noted and process was repeated for three times. Only those bacterial pathogens were noted which gave same result every time.

The instructions provided by Merck science lab Rawalpindi were followed to get the results. For Lactose test color change was noted as positive after broth culture. Indole test was noted as positive by appearance of pink red layer. Red color formation after addition of alpha-naphthol+sodium hydroxide while shaking the tube for 10 minutes was an indication of positive result for VogesProskauer test. Green color change to blue confirmed the positive result for Citrate test. For Nitrate test the color changed into dark red within 5-10 minutes. This test was carried with the addition of N,Ndimethyl-1-naphthylamine and sulphuric acid. The Oxidase test gave positive by appearance of purple color after applying $1 \%$ tetramethylp-phenylenediamine dihydrochloride on filter paper. For Catalase test the oxygen bubbles demonstrated positive result. Black precipitates affirmed positive test for $\mathrm{H}_{2} \mathrm{~S}$. Appearance of reddish color during Methyl Red test confirmed positive results for presence of $E$. coli. The yellow color was commuted to red for urease test indicating positive result. Visualizing under microscope, a hazy zone (irregular movement) formation confirmed the positive result for motile bacteria and a single line of growth formation indicated presence of non-motile bacteria. Regain of purple color from yellow color after 48 hours' incubation confirmed positive result for Ornithine test. Maltose test showed positive result after conversion of red color to yellow color. Here phenol red was used as $\mathrm{PH}$ indicator. In case of Mannose test the normal red color (phenol red indicator) commuted to yellow or pink, an indication of positive result. Similarly, Inositol test was noted positive by color transformation from red (phenol red indicator) to yellow or pink. For the Trehalose test the transformation of red color to yellow affirmed positive result. For sucrose test the color change from red to yellow was observed as an indication of positive result. For acetate test the clear zone formation was an indication of the acetic acid producing bacteria so it was considered positive for Acetobacter. For Triple Sugar Iron and Lysine Iron Agar tests the color change, butt and gas production was noted to the slants and compared the information available in the list provided by science lab Rawalpindi Pakistan. Gelatine hydrolysis test was performed and the starch hydrolization by making clear zones in surrounding was noted for positive results after addition of iodine. Lysine decarboxylase test was noted as positive by the color change to purple. A small amount of oil was added to prevent oxygen from moving out. In Coagulase test the clot formation indicated positive result. For Pyruvate test the change of blue green color to yellow was taken as confirmation of positive result. In Arginine test the purple color was changed to yellow, which is acquired as an indication of positive result. Tellurite test was confirmed as positive by the appearance of grey color on the growing colonies. In mannitol test the red color change to yellow confirmed the positive result. Furazolidone test was performed and the resistance or sensitivity was observed and compared to the list of information provided by science lab Rawalpindi Pakistan.

\section{RT-PCR and gel electrophoresis}

HCV RNA isolation from concentrated water samples were carried out using the Water RNA/DNA purification kit (NORGEN Biotek, Canada), according to manufacturer's instructions. The extracted RNA was reverse transcribed into cDNA. The amplified cDNA/DNA was subjected to PCR amplification. The PCR product was run on gel electrophoresis followed by observation of the obtained bands through gel documentation.

\section{Results}

\section{Identification of bacterial pathogens}

Determination of pathogenic bacteria and viruses by conventional culturing and molecular techniques, respectively, is a reliable approach for assessment of water quality. Only those pathogens were included in final results which were found throughout the year in collected samples to make sure the presence of microbes regardless of physiological effect and environmental changes. Therefore, it is concluded that these pathogens made the studied sites their permanent habitat. Out of all the samples analysed, $42 \%$ pathogens were identified in drinking water and $58 \%$ pathogens in sewage water samples. Considering overall results (drinking and sewage water samples), KTH samples were highly contaminated (40\%), followed by DG (31\%) and HMC (29\%) with little difference in results. Common bacterial pathogens traced in drinking water samples collected from all sites indicated that KTH water being highly contaminated had 10 different pathogenic species, HMC had 6, whereas, 4 different pathogenic species were detected in DG water. However, in case of sewage water, high species diversity was observed in DG samples that was contaminated with 14 different pathogenic species, as compared to 13 and 11 different pathogenic species investigated from HMC and KTH respectively. Besides common bacterial pathogens, some other important but seldom bacterial (Mycobacterium tuberculosis) pathogens were also identified in sewage water samples. Among the identified pathogens, Klebsiella pneumoniae and S. aureus were detected frequently, as compared to Proteus mirabilis, Psudomonas aeruginosa and Enterococcus faecalis, which were least common observed pathogens in all samples. Paradoxically, fresh water samples collected from DG had shown presence of Proteus vulgaris, and $M$. tuberculosis in sewage water that was present in almost $80 \%$ of all the samples collected from different locations of DG. The largest number of pathogenic bacterial species in fresh water systems was found in KTH samples, while the lowest number of pathogenic bacteria species in fresh water sources was found at HMC. However, in sewage water systems the largest numbers of bacterial species were observed at DG and the lowest numbers of bacterial pathogens were detected at HMC. A detailed list of bacterial pathogens identified in each sampling site is given in Table 2 .

\section{Identification of viral pathogens}

Water samples collected from multiple sites of DG, KTH and $\mathrm{HMC}$ was further investigated for the presence of viral pathogens i.e., $\mathrm{HCV}$ and $\mathrm{HBV}$. Sewage water samples collected from KTH and DG determined presence of $\mathrm{HBV}$, whereas, HCV was only detected in the sewage water samples collected from KTH. However, no viral pathogens were detected in fresh water samples collected from any studied area (Table 2; Figure 1).

\section{Comparative analysis for pathogens identified in healthcare centres}

Based on type of species, comparatively more pathogens were detected in sewage water, that is, total 17 different types of pathogens were ascertained in sewage water and 11 in fresh water systems (Figure 2). 
Citation: Suliman K, Siddique R, Nabi G, Li Q, Hou H, et al. (2017) Investigation of Sewage and Drinking Water in Major Healthcare Centres for Bacterial and Viral Pathogens. Hydrol Current Res 8: 272. doi: 10.4172/2157-7587.1000272

Page 4 of 7

\begin{tabular}{|c|c|c|c|c|c|c|c|c|c|c|}
\hline Pathogen & $\begin{array}{l}\text { Health hazard } \\
\text { caused }\end{array}$ & $\begin{array}{l}\text { Detection } \\
\text { Method }\end{array}$ & Selective media & $\begin{array}{c}\text { Colony } \\
\text { appearance }\end{array}$ & $\begin{array}{l}\text { KTH } \\
\text { F.W }\end{array}$ & $\begin{array}{l}\text { KTH } \\
\text { S.W }\end{array}$ & $\begin{array}{l}\text { DG } \\
\text { F.W }\end{array}$ & $\begin{array}{l}\text { DG } \\
\text { S.W }\end{array}$ & $\begin{array}{l}\text { HMC } \\
\text { F.W }\end{array}$ & $\begin{array}{l}\text { HMC } \\
\text { S.W }\end{array}$ \\
\hline Escherichia coli & $\begin{array}{l}\text { Urinary tract infection, } \\
\text { neonatal meningitis } \\
\text { and food poisoning }\end{array}$ & $\begin{array}{c}\text { Culture/ } \\
\text { biochemical }\end{array}$ & EMB agar & $\begin{array}{l}\text { Metallic green } \\
\text { sheen }\end{array}$ & + & + & + & + & - & + \\
\hline Enterobacteraerogenes & $\begin{array}{l}\text { Urinary and } \\
\text { respiratory tract } \\
\text { infections }\end{array}$ & $\begin{array}{c}\text { Culture/ } \\
\text { biochemical }\end{array}$ & EMB agar & $\begin{array}{c}\text { Pink color of } \\
\text { bacterial growth }\end{array}$ & - & - & - & + & - & + \\
\hline Haemophilusinfluenza & $\begin{array}{l}\text { Pneumonia, } \\
\text { septicemia, } \\
\text { meningitis and skin } \\
\text { infection }\end{array}$ & $\begin{array}{c}\text { Culture/ } \\
\text { biochemical }\end{array}$ & Chocolate agar & $\begin{array}{l}\text { Offwhite distinct } \\
\text { colonies with } \\
\text { pungent smell }\end{array}$ & + & - & - & + & - & + \\
\hline Klebsiellapneumoniae & $\begin{array}{l}\text { Pneumonia, } \\
\text { septicemia and } \\
\text { ankylosing }\end{array}$ & $\begin{array}{c}\text { Culture/ } \\
\text { biochemical }\end{array}$ & McConkey agar & $\begin{array}{l}\text { Pink colored } \\
\text { round and } \\
\text { long branched } \\
\text { colonies }\end{array}$ & + & + & + & + & + & + \\
\hline Serratiamarcescens & $\begin{array}{l}\text { Urinary tract } \\
\text { infection, septicemia, } \\
\text { meningitis and } \\
\text { endocarditis }\end{array}$ & $\begin{array}{c}\text { Culture/ } \\
\text { biochemical }\end{array}$ & XLD agar & $\begin{array}{l}\text { Light pink round } \\
\text { colonies }\end{array}$ & + & - & - & + & + & + \\
\hline Hafniaalvei & $\begin{array}{c}\text { Urinary tract infection } \\
\text { and diarrhea }\end{array}$ & $\begin{array}{c}\text { Culture/ } \\
\text { biochemical }\end{array}$ & McConkey agar & $\begin{array}{l}\text { Light brown } \\
\text { rough colonies }\end{array}$ & - & + & - & + & - & - \\
\hline Proteus vulgaris & $\begin{array}{l}\text { Urinary tract } \\
\text { infections }\end{array}$ & $\begin{array}{c}\text { Culture/ } \\
\text { biochemical }\end{array}$ & HE \& XLD agar & $\begin{array}{l}\text { Yellow orange } \\
\text { colonies }\end{array}$ & - & - & + & - & - & - \\
\hline Proteus mirabilis & $\begin{array}{l}\text { Urinary tract } \\
\text { infections }\end{array}$ & $\begin{array}{c}\text { Culture/ } \\
\text { biochemical }\end{array}$ & XLD agar & $\begin{array}{l}\text { Orange colonies } \\
\text { with white center }\end{array}$ & - & + & - & + & - & + \\
\hline Salmonella enterica & $\begin{array}{l}\text { Enteric fever, } \\
\text { paratyphoid fever, } \\
\text { septicemia and } \\
\text { salmonellosis }\end{array}$ & $\begin{array}{c}\text { Culture/ } \\
\text { biochemical }\end{array}$ & $\begin{array}{c}\text { MSRV agar \& XLD } \\
\text { agar }\end{array}$ & $\begin{array}{c}\text { Red colonies } \\
\text { with black center, } \\
\text { straw colonies } \\
\text { with hallow zone } \\
\text { around }\end{array}$ & - & + & - & + & - & - \\
\hline Shigelladysentriae & Shigellosis & $\begin{array}{c}\text { Culture/ } \\
\text { biochemical }\end{array}$ & $\begin{array}{c}\mathrm{HE} \text { agar \& XLD } \\
\text { agar }\end{array}$ & $\begin{array}{l}\text { Red to pink } \\
\text { colonies }\end{array}$ & + & + & - & + & + & + \\
\hline Providenciastuartii & $\begin{array}{c}\text { Gastroenteritis and } \\
\text { bacteremia }\end{array}$ & $\begin{array}{c}\text { Culture/ } \\
\text { biochemical }\end{array}$ & MU/SC agar & $\begin{array}{l}\text { Yellowish orange } \\
\text { centred colonies }\end{array}$ & - & - & - & + & - & - \\
\hline $\begin{array}{l}\text { Pseudomonas } \\
\text { aeruginosa }\end{array}$ & $\begin{array}{l}\text { Urinary tract infection, } \\
\text { pulmonary tract } \\
\text { infection, wounds and } \\
\text { burns infections }\end{array}$ & $\begin{array}{c}\text { Culture/ } \\
\text { biochemical }\end{array}$ & TSA agar, $\mathrm{PI}$ agar & $\begin{array}{l}\text { Brown colonies, } \\
\text { Blue, Green } \\
\text { colonies }\end{array}$ & - & + & - & - & - & + \\
\hline Salmonella typhi & Typhoid & $\begin{array}{c}\text { Culture/ } \\
\text { biochemical }\end{array}$ & HE agar & $\begin{array}{l}\text { Blue green } \\
\text { colonies with } \\
\text { dark center }\end{array}$ & + & + & - & - & - & + \\
\hline Staphylococcus aureus & $\begin{array}{c}\text { Meningitis, } \\
\text { pneumonia, } \\
\text { gastroenteritis and } \\
\text { wound infections }\end{array}$ & $\begin{array}{c}\text { Culture/ } \\
\text { biochemical }\end{array}$ & TS agar,MSA & $\begin{array}{l}\text { White round } \\
\text { colonies }\end{array}$ & + & + & - & - & - & + \\
\hline Enterococcus faecalis & $\begin{array}{l}\text { Bacterimia, urinary } \\
\text { tract infection and } \\
\text { meningitis }\end{array}$ & $\begin{array}{c}\text { Culture/ } \\
\text { biochemical }\end{array}$ & Blood agar & $\begin{array}{l}\text { circular, convex } \\
\text { white colonies }\end{array}$ & - & - & - & + & - & - \\
\hline Aeromonashydrophila & $\begin{array}{l}\text { Aerolysin Cytotoxic } \\
\text { Enterotoxin (ACT) } \\
\text { production causes } \\
\quad \text { tissue damage }\end{array}$ & $\begin{array}{c}\text { Culture/ } \\
\text { biochemical }\end{array}$ & CLED/TCBS agar & $\begin{array}{l}\text { Yellow round } \\
\text { with full margin } \\
\text { colonies }\end{array}$ & + & - & - & - & + & - \\
\hline Aeromonassobria & $\begin{array}{c}\text { Foodbrone diseases, } \\
\text { diarrhea and wound } \\
\text { infections }\end{array}$ & $\begin{array}{c}\text { Culture/ } \\
\text { biochemical }\end{array}$ & CLED agar & $\begin{array}{l}\text { Round colonies } \\
\text { with white } \\
\text { margins }\end{array}$ & + & + & - & - & + & - \\
\hline $\begin{array}{l}\text { Staphylococcus } \\
\text { epidermidis }\end{array}$ & $\begin{array}{c}\text { Skin infections, } \\
\text { meningitis, } \\
\text { osteomyelitis, toxic } \\
\text { shock syndrome and } \\
\text { pneumonia }\end{array}$ & $\begin{array}{c}\text { Culture/ } \\
\text { biochemical }\end{array}$ & $\begin{array}{c}\text { Blood agar, MS } \\
\text { agar }\end{array}$ & $\begin{array}{l}\text { White colored } \\
\text { full margined } \\
\text { colonies }\end{array}$ & + & + & + & + & + & + \\
\hline $\begin{array}{l}\text { Mycobacterium } \\
\text { tuberculosis }\end{array}$ & Tuberculosis & $\begin{array}{c}\text { Culture/ } \\
\text { biochemical }\end{array}$ & LJ medium & $\begin{array}{l}\text { Granular light } \\
\text { brown colonies } \\
\text { with rough } \\
\text { surface }\end{array}$ & - & - & - & + & - & - \\
\hline Virus & Hepatitis C & PCR & $\mathrm{N} / \mathrm{A}$ & & - & + & - & - & - & - \\
\hline Virus & Hepatitis B & PCR & $\mathrm{N} / \mathrm{A}$ & & - & + & - & + & - & - \\
\hline
\end{tabular}

Table 2: Identification of pathogenic microorganisms in fresh water (F.W) and sewage water (S.W) samples collected from different healthcare centers. The table also illustrates the health hazards caused by the detected microorganisms and the detection methods and media used. The,+- sings indicate the presence and absence of microorganism in the specified region respectively. 


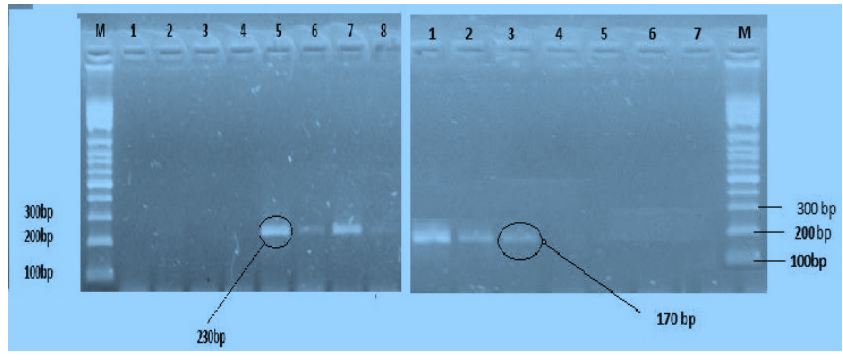

Figure 1: Both HCV and HBV targeted amplicons of size 170 and 230 bp respectively, were isolated from sewage water of major healthcare centers in Peshawar. HCV was detected in water samples collected from KTH, whereas HBV was detected in sewage water samples collected from KTH and DG.

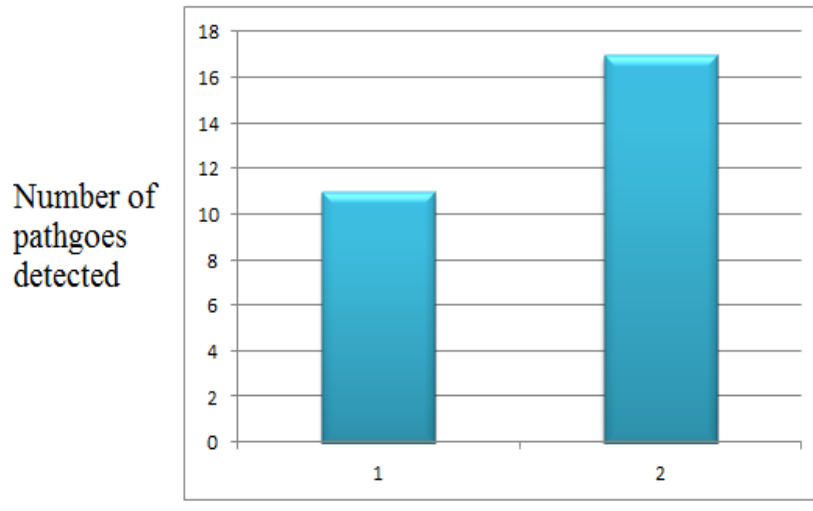

Fresh water

Sewage water

Figure 2: Comparative analysis of fresh water and sewage water samples regarding numbers of identified bacterial pathogens. This figure shows that out of the total identified bacterial species 17 types of species were present in the fresh water whereas 11 types of species were detected in fresh water.

DG sewage water contains the most diverse species of pathogens while its fresh water sources contain the least pathogenic species, as shown in Figure 3.

Most frequently observed pathogens in either fresh water or sewage water samples from all sample collecting sites were klebsiella and Staphylococcus epidermidis, whilst the least common pathogens were Proteus vulgaris, Providencia, Enterobacter faecalis and Mycobacterium tuberculosis (Figure 4).

The overall result of both fresh and sewage water sources confirmed that KTH samples were comparatively more contaminated than DG/ DBG and HMC (Figure 5). The least number of the bacterial species in DBG makes it safer than others and it might be due the privatized sector is taking better care to dispose the materials. Although there was no cleaning and burning systems but the lower bacterial burdens in water samples indicated the better treatment of wastes comparatively the other two sectors. KTH water indicated the most risk posing among all the investigated healthcare centers. It shows that lesser attention is provided to the treatment.

Considering samples (both fresh and waste water) collected from each sample collecting site/health care units, the highest numbers of pathogens were observed in sewage water i.e., $11.77^{\mathrm{a}} \pm 0.57$. Besides in sewage water the maximum numbers of pathogens were found in DG i.e., $13.33 \pm 0.66$ as compared to HMC i.e., $10.33 \pm 0.66$ where the lowest numbers of pathogens were detected. However, in case of fresh water, the maximum numbers of pathogens were found in $\mathrm{KTH}$, whilst the minimum numbers of pathogens were identified in DG (Table 2). From overall result, it is evident that KTH water is highly contaminated and inadequate for consumption having highest number of pathogenic species i.e., $10.66^{\mathrm{a}} \pm 0.61$, whilst the lowest number of pathogens identified in $\mathrm{HMC}$ i.e., $8.00^{\mathrm{b}} \pm 1.09$ is also not safe to use.

\section{Discussion}

For all living organisms water is the most vital and important factor of survival. Inadequate access to clean water, inappropriate water treatment and bad sanitation systems is one of the most pervasive issues distressing people throughout the globe, causing waterborne infectious diseases, cause approximately 10 million deaths per year $[3,20,21]$. Human health is prone to microbial risks caused by enteric viruses and bacteria [22]. Studies have shown that contaminated drinking water has been source of several critical diseases, for instance, diarrhea, nausea, Cholera, typhoid, dysentery, abdominal pain and food poisoning. Situation is even worst at health care centres, where drinking water is source of pathogens transmission showing negligence of managerial authority towards supplying properly treated water. Variant pathogens are observed in ground and surface water, flood and dam water [23-25]. Furthermore, presence of bacterial pathogens is associated with physiochemical characters and location of drinking water sites [26]

To the best of our knowledge, the present study is the first systematic analysis on water sources of healthcare centres of Peshawar, KPK, Pakistan highlighting the presence of multiple substantial bacterial pathogens in hospital's drinking and sewage water [27]. List of variant infectious bacterial and viral pathogens identified in water samples that were present consistently throughout the year at $\mathrm{KTH}, \mathrm{DB}$ and $\mathrm{HMC}$ are given in Table 1. The abundancy of these pathogens in water sources calls out for appropriate initiatives to be taken to curb outbreak of waterborne epidemics associated with contaminated water consumption [28]. In different sites the variation is characterized by physiochemical differences of the water sources [26]. Presence of Hepatitis B and $C$ viruses in open water sources causes death of $60 \%$ of the affected people if persists for a longer time and proliferate continuously $[29,30]$, are associated with serious public health issues $[29,31]$. Most frequently reported pathogenic species considering all water samples are E. coli, S. auerus, K. pneumonia, S. typhi and $P$. aeruoginosa $[2,26,32]$, on the basis of current study it is suggested that consumption of such water is threat to public health.

In our analysis the pathogens investigated can cause severe health problems in humans [9,33]. Most of the bacterial pathogens detected have been reported previously to be present in common water sources or home based drinking water sources $[23,26]$ but their presence in the water sources of healthcare centers was not considered to be investigated. Furthermore, DG fresh water sources were contaminated with one third of pathogens number to that of KTH. We suggested that this high number of pathogens might be because of the improper water supply sources where sewage water can get entered into drinking water sources because of leakages in pipelines. Interestingly P. Vulgaris was only found in fresh water of DG but it was not detected in sewage water sources or other fresh water sources. Analysis of sewage water allowed us to detect diverse numbers of pathogens, the highest number in DG. The presence of K. pneumonia and S. auerus in all 


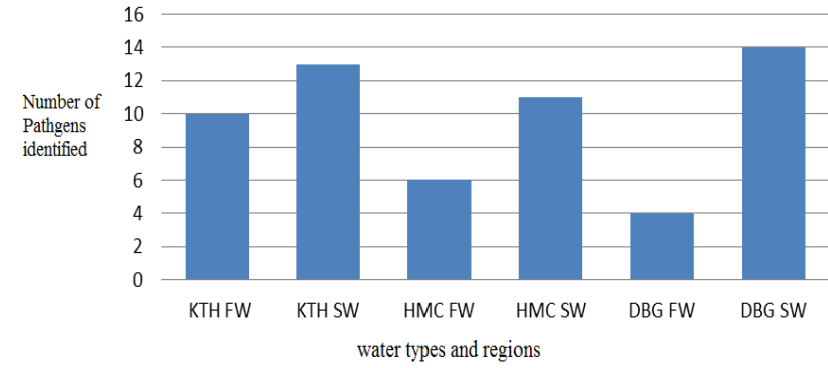

Figure 3: Comparison between different regions regarding specie type based numbers of pathogens identified. This figure illustrates that fresh water of KTH had 10 different bacterial species where its sewage water had 13 different bacterial species. In HMC 6 different types of bacterial species were identified in fresh water sources and 11 bacterial species were found in sewage water sources. The numbers of pathogenic species were 4 and 14 in fresh and sewage water respectively in samples collected from DBG.

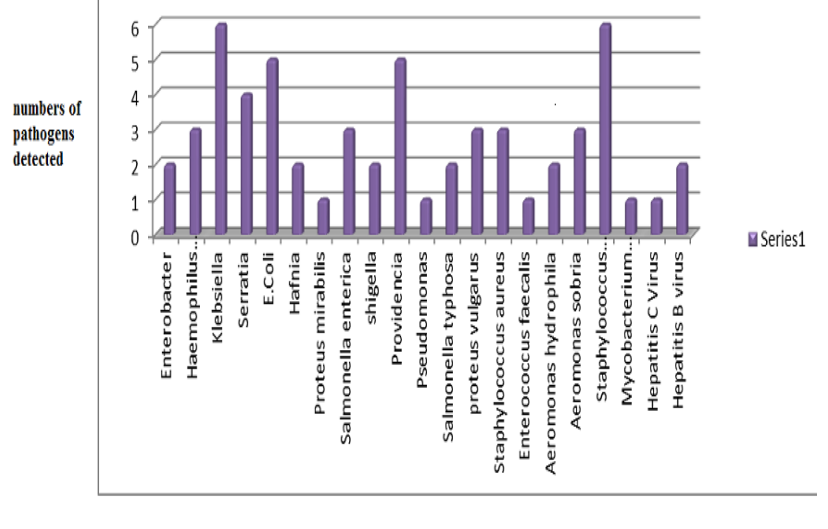

pathogens

Figure 4: This figure illustrates that Staphylococcus aureus and Klebsiella were among the abundance bacterial pathogens. These species were found in all of the samples collected from the three healthcare centers. E. coli and Providencia were the second most abundant bacterial pathogens. In this list the least abundant bacterial pathogens were Mycobacterium, Pseudomonas, Hafnia, HCV and HBV which were found in only one type of the water samples.

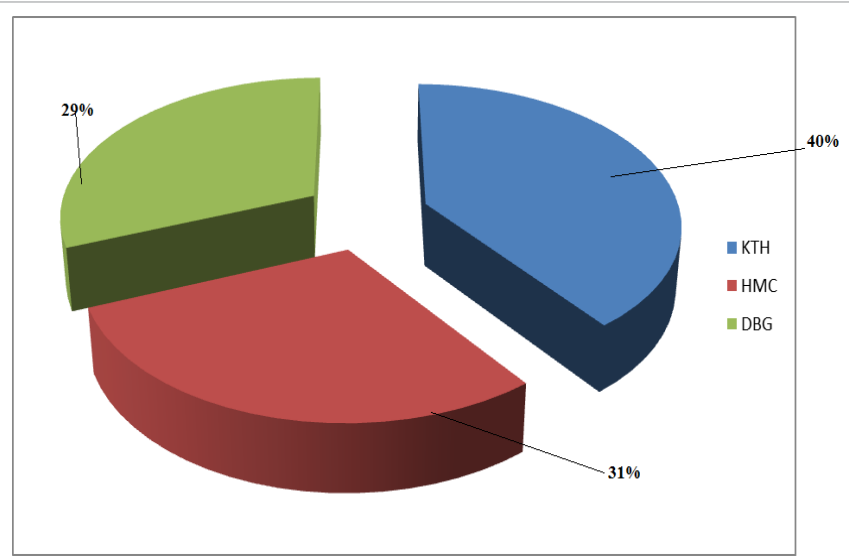

Figure 5: This figure illustrates the pathogens burden in the healthcare centers The highest bacterial burdens were found KTH which is one of the biggest hospitals of the city. It had $40 \%$ of the total bacterial species burden whereas $\mathrm{HMC}$ had $31 \%$ and was ranked second. The safer among all was DBG where the total bacterial burden was $29 \%$. sites regardless of the water type is an indication that these are the permanent species as these were also reported in daily used water sources in surrounding regions [26]. P. mirabilis, P. aeruginosa and $E$. faecalis were unexpectedly found in the least sites as these are generally found in water sources of diverse locations $[23,27]$. In addition $P$. stuartii was interestingly found in almost all water sources, which was considered to be present at most in sewage water sources only. A. sobria presence was detected in fresh water of KTH too which is an unexpected result. Other bacterial pathogens (except M. tuberculosis) were found in diverse sites as they are generally considered to be found in water sources $[26,28]$. Surprisingly the viral species were detected in KTH and DG sewage water which is a threat to treatment seekers and patients care takers. We investigated that some highly pathogenic bacteria including $M$. tuberculosis were present persistently throughout the study period. Furthermore, the viral pathogens were also detection continuously throughout the year, which indicates that no proper treatment is carried to the water sources.

To our knowledge, in hospitals, fluids from diagnostic tests and laboratories are improperly disposed of allowing pathogenic bacteria and viruses to contaminate water that runs off to the tap water and sewage systems, subsequently contaminating drinking water. The investigated pathogens, however, may be present in fresh water due to the lack of management interest in providing properly treated water wiped off from the pathogenic bacterial species; and treatment of hospital wastes accurately before disposing it. At the same time the laboratories owners are not admonished to throw the wastes in open places. Other sources of bacterial contamination of fresh water are surface runoff through hospitals and urban areas, pastures and agricultural lands, leakage of sewage disposal systems and septic tanks, overloaded sewage treatment plants, disposal systems and raw sewage deep well injection $[2,9,34]$. Similarly, we propose that contamination of drinking water observed during the present study involves factors like cross-connections, broken or leaking pipes, back-siphonage (backflow of polluted or contaminated water, from a plumbing fixture or cross-connection into a water supply line, due to a lowering of the pressure in the line) and intermittent water supply $[9,34,35]$, and these pathogens have made the studied sites as their permanent habitats.

Our approach offers an unbiased identification of those bacterial and viral pathogens which can lead to serious human health problems. The overall investigated pathogens in hospital's water samples are similar to the investigations of other water sources either drinking water, dam water, flood water or sewage water in KPK [26,27], somehow, our results differ in a way that through our investigation few uncommon bacterial pathogens like $M$. tuberculosis, and exceptional viral species are also identified. The reason might be the investigation site (hospitals) and consideration of only those pathogens in the results which were found in all sample collection sites and present throughout the year.

\section{Conclusions}

We came up with a conclusion that if current condition continued water borne illnesses will pose serious threat to public health. Addressing existence of disease causing pathogens in water sources for instance, E. coli, S. aureus, P. stuartii, K. pneumonia, H. influenzae, and $P$. sobira, calls out for a tremendous amount of research to be conducted to identify robust new water purifying techniques at lower 
Citation: Suliman K, Siddique R, Nabi G, Li Q, Hou H, et al. (2017) Investigation of Sewage and Drinking Water in Major Healthcare Centres for Bacterial and Viral Pathogens. Hydrol Current Res 8: 272. doi: 10.4172/2157-7587.1000272

cost, with minimal use of chemicals. These pathogens can enter into water pipelines through back-siphon age, cross-connections, broken or leaking rusted pipelines, thus intermittent water supply results in contamination of the distribution system. Hospital's waste and patient's fluid should be disposed of properly. It is encouraged to drink boiled water and have drinking utensils autoclaved, since most bacterial and viral pathogens cannot survive in boiled water.

\section{Acknowledgements}

This work was supported by Relief International, Pakistan and State Key Laboratory of Freshwater Ecology and Biotechnology (Grant No. Y119011F01) and CAS-TWAS.

\section{Conflict of Interest}

The authors declare that there is no conflict of interests regarding the publication of this paper.

\section{References}

\section{UNESCO (2003).}

2. Sardar K, Irfan AS, Said M, Riffat NM, Mohammad TS (2005) Arsenic and Heavy Metal Concentrations in Drinking Water in Pakistan and Risk Assessment: A Case Study. Hum Ecol. Risk. Assess 21: 1020-1031.

3. Akbar A, Sitara U, Khan SA, Muhammad N, Khan MI, et al. (2013) Driniking water quality and risk of waterborne diseases in the rural mountainous area of Azad Kashmir Pakistan. Intl. J. Biosci. 3: 245-251.

4. Jarraud S, Mougel C, Thioulouse J, Lina G, Meugnier H, et al. (2002) Relationships between Staphylococcus aureus genetic background, virulence factors, age groups (alleles) and human disease. Infec. Immunol. 70: 631641

5. Herold S, Karch H, Schmidt H (2004) Shiga toxin-encoding bacteriophagesgenomes in motion. Intl. J Med Microbiol 294: 115-121.

6. Feigin V, Brainin M, Breteler MMB, Martyn C, Wolfe C, et al. (2004) Teaching of neuroepidemiology in Europe: time for action. Euro $\mathrm{J}$ Nerol 11: 795-799.

7. Wang L, He Y, Xia Y, Wang H, Liang S (2014) Investigation of mechanism and molecular epidemiology of linezolid-resistant Enterococcus faecalis in China. Inf Genet Evol 14: 160-169.

8. Rosina G, Ferru MA, Alonso JL, Manzano JR, Calgua B, et al. (2010) Molecular detection of pathogens in water-the pros and cons of molecular techniques. Water Res 44: 4325-4329.

9. Azizullah A, Khattak MN, Richter P, Häder DP (2011) Water pollution in Pakistan and its impact on public health. Environ Intl 37: 479-497.

10. Khan S, Shahnaz M, Jehan N, Rehman S, Shah MT, et al. (2013) Drinking water quality and human health risk in Charsadda district, Pakistan. J Cleaner Prod 60: 93-101.

11. Friedlander LR, Puri N, Schoonen MA, Wali Karzai A (2015) The effect of pyrite on Escherichia coli in water: proof-of-concept for the elimination of waterborne bacteria by reactive minerals. J Water Health 13: 42-53.

12. Gomez-Alvarez V, Humrighouse BW, Revetta RP, Domingo JWS (2015) Bacterial composition in a metropolitan drinking water distribution system utilizing different source waters. J Water Health pp: 57.

13. September SM, Els FA, Venter SN, Brözel VS (2007) Prevalence of bacterial pathogens in biofilms of drinking water distribution systems. J Water Health 5: 219-227.

14. Tassadaq H, Roohi A, Munir S, Ahmed I, Khan J, et al. (2013) Biochemical characterization and identification of bacterial strains isolated from drinking water sources of Kohat, Pakistan. Afr J Microbiol Res 7: 1579-1590.

15. Mody RK, Meyer S, Trees E, White PL, Nguyen T, et al. (2014) Outbreak of Salmonella enterica serotype | 4,5,12 i: infections: the challenges of hypothesis generation and microwave cooking. Epidemiol Infec 142: 1050-1060.

16. Nele W, Frost C, Marre R (2001) Detection of Legionellae in Hospital Water Samples by Quantitative Real-Time Light Cycler PCR. App Environ Microbiol 67: 3985-3993.

17. Thomas S, Kohnen W, Jansen B, Obst U (2002) Detection of antibiotic- resistant bacteria and their resistance genes in wastewater, surface water, and drinking water biofilms. FEMS Microb Ecol 43: 325-335.

18. Audemard C, Reece KS, Burreson EM (2004) Real-Time PCR for detection and quantification of the protistan parasite Perinsusmarinus in environmental waters. App Environ Microbiol 70: 6611-6618.

19. Largus TA, Kelley ST, Amand AS, Pace NR, Hernandez MT (2005) Molecular identification of potential pathogensin water and air of a hospital therapy pool. PNAS 102: 4860-4865.

20. Pindi PK, Yadav PR, Shanker AS (2013) Identification of Opportunistic Pathogenic Bacteria in Drinking Water Samples of Different Rural Health Centers and Their Clinical Impacts on Humans. Biomed Res intl. Article ID 348250.

21. Baudart J, Coallier J, Laurent P, Prevost M (2002) Rapid and Sensitive Enumeration of Viable Diluted Cells of Members of the Family Enterobacteriaceae in fresh water and drinking water. Appl Environ Microbiol 68: 5057-5063.

22. Podschun R, Ullmann U (1989) Klebsiella spp. as nosocomial pathogens: epidemiology, taxonomy, typing methods and pathogenicity factors. Clin Microbiol 11: 589-603.

23. Shar AH, Kazi YF, Kanhar NA, Soomro IH, Zia SM, et al. (2010) Drinking water quality in Rohri City, Sindh, Pakistan. Afr J of Biotech 9: 7102-7107.

24. Ahmed T, Kanwal R, Tahir SS, Rauf N (2004) Bacteriological analysis of water collected from different dams of Rawalpindi/lslamabad region in Pakistan. Pak J Biolo Sci 7: 662-666.

25. Khan FA, Ali J, Ullah R, Ayaz S (2014) Bacteriological quality assessment of drinking water available at the flood affected areas of Peshawar. Toxicol \& Environ Chem pp: 1448-1454.

26. Ahmad B, Aquat ML, Ali J, Bashir S, Mohammad S, et al. (2014) Microbiology and Evaluation of Antibiotic Resistant Bacterial Profiles of Drinking Water in Peshawar, Khyber Pakhtunkhwa. World App Sci J 30: 1668-1677.

27. Hussain T, Roohi A, Munir S, Ahmed I, Khan J, et al. (2013) Biochemical characterization and identification of bacterial strains isolated from drinking water sources of Kohat, Pakistan African Journal of Microbiology Research 7: $1579-1590$

28. Fong TL, Shindo M, Feinstone SM, Hoofnagle JH, Bisceglie AM (1991) Detection of replicative intermediates of hepatitis $C$ viral RNA in liver and serum of patients with chronic hepatitis C. J Clin Invest 88: 1058-1060.

29. Liu WC, Liu QY (2014) Molecular mechanisms of gender disparity in hepatitis B virus-associated hepatocellular carcinoma. W J Gastroenterol 20: 62526261.

30. Maan R, Veldt BJ, Janssen V (2014) Eltrombopag for Thrombocytopenic Patients with Chronic HCV Infection. Gastroenterol 16: 53-63.

31. Radcliffe RA, Bzixler D, Moorman A, Hogan VA, Greenfield VS, et al. (2013) Hepatitis B virus transmissions associated with a portable dental clinic West Virginia. J Ameri Dent Asso 144: 1110-1118.

32. PCRWR. Annual Report 2005-2006. Islamabad, Pakistan: Pakistan Council for Research in Water Resources, 2008. Available online at http:// www.pcrwr.gov.pk/Annual\%20Reports/New\%20Annual\%20Repot\%20 200506_2.pdf.

33. Ravasan NM, Oshaghi MA, Sara H, Zahra S, Amir AA, et al. (2014) Aerobic microbial community of insectary population of Phlebotomus papatasi. J Arthr Bor Dis 8: 69-81.

34. Sarah PW, Victor PJG, Katharine GF (2007) Detection of Bacteroidales Fecal Indicators and the Zoonotic Pathogens E. coli O157:H7, Salmonella and Campylobacter in River Water. Environ Sci Technolo 41: 1856-1862.

35. Marta R, Jurek T, Szleszkowski L, Gladysz A (2014) Outbreak of hepatitis C among patients admitted to the Department of Gynecology, Obstetrics, and Oncology. American J Infec Cont 429: 7-10. 